\title{
CHANGES IN E-EDUCATION BROUGHT BY THE COVID-19 PANDEMIC IN POLAND: BEHAVIOUR AND PERCEPTIONS OF YOUNG E-EDUCATION SERVICE CONSUMERS AND SERVICE PROVIDERS
}

\author{
ZMIANY NA POLSKIM RYNKU USŁUG E-EDUKACJI SPOWODOWANE PANDEMIĄ COVID-19: \\ ZACHOWANIA I OPINIE MŁODYCH KONSUMENTÓW I USŁUGODAWCÓW
}

\author{
Anna Dąbrowska \\ Warsaw School of Economics, Institute of Management, Consumer Behaviour Research Department \\ Warsaw, ul. Madalińskiego 6/8 \\ adabro3@sgh.waw.pl O ORCID 0000-0003-1406-5510 \\ Joanna Ciupak \\ graduate of the Warsaw School of Economics \\ Warsaw, ul. Madalińskiego 6/8 \\ DOl: 10.2478/minib-2021-0014
}

\section{ABSTRACT}

This study - carried out in May 2020, early on during the COVID-19 pandemic - examines the situation in the Polish e-education market, as perceived by secondary school and university students who consume e-education services and by the providers of such services. Firstly, to set the stage, in-depth interviews were carried out with eight owners of companies offering commercial e-education services. Next, an extensive online survey was carried out among secondary school and university students in the 2019-2020 school/academic year using the CAWI method on a sample of 803 respondents - with secondary school students (group I) accounting for $30 \%$ of the sample and university students (group II) making up the remaining $70 \%$ - concerning their satisfaction or dissatisfaction with e-education services. Taken together, the findings allow for an assessment of the advantages and disadvantages of distance learning and point to the increased demand for e-education services during the pandemic, in tandem with a continually shifting e-education services market.

Key words: e-education consumers, e-education providers, secondary school students, university students, COVID-19 pandemic 


\section{ABSTRAKT}

W niniejszym badaniu, przeprowadzonym w maju 2020 roku na początku pandemii COVID-19, analizowano sytuację na polskim rynku e-edukacji, odzwierciedloną w opiniach uczniów szkół średnich i studentów korzystających z usług e-edukacji oraz opiniach dostawców tychże usług. Przeprowadzono wywiady pogłębione z próbą celową ośmiu właścicielami firm oferujących komercyjne usługi e-edukacyjne. Następnie wśród uczniów szkół średnich i studentów w roku szkolnym/akademickim 2019-2020 przeprowadzono badanie na temat ich zadowolenia lub niezadowolenia z usług e-edukacji, z wykorzystaniem kwestionariusza ankiety online (metodą CAWI) na próbie 803 respondentów. Uczniowie szkół średnich (grupa I) stanowili 30\% próby, a studenci uczelni wyższych (grupa II) pozostałe 70\%. Uzyskane wyniki pozwalają na ocenę zalet i wad kształcenia na odległość oraz wskazują na zwiększony popyt na usługi e-edukacyjne w czasie pandemii i inne postępujące zmiany na polskim rynku usług e-edukacyjnych.

Słowa kluczowe: usługodawcy e-edukacji, konsumenci e-edukacji, uczniowie szkół średnich, studenci, pandemia COVID-19

JEL: $121,1210,1250$

\section{Introduction}

Education is the key determinant of socioeconomic and cultural wellbeing. In the era of globalization, innovation and competitiveness in various areas of economic and social life, education remains high on the list of priorities, and lifelong learning has become an established paradigm. Education plays a major role in the life of every human being, starting from compulsory education in primary school, ${ }^{1}$ through secondary school, the choice of university studies, the acquisition of professional skills and further qualifications, all the way to self-development and the pursuit of passions and interests.

At the same time, education is - alongside healthcare - among the areas of socioeconomic life that have been particularly strongly affected by 
the COVID-19 pandemic. School closures caused by COVID-19 affected over $90 \%$ of the world's enrolled learners (Strauss, 2020), which upended the education landscape. The effects have been experienced by learners in all types of education institutions: from pre-primary schools to universities (United Nations, 2020). In addition, the pandemic has impacted those planning to study abroad (Dhungana, 2020).

However, even before the outbreak of the pandemic, interest in new technologies in education had already been visibly on the rise. Global investments in educational technology (EdTech) reached USD 18.66 billion in 2019 , and the overall online education market is expected to reach USD 350 billion by 2025 . Since the outbreak of the pandemic, however, there has only been even faster growing interest in language applications, virtual tutoring, video conferencing tools and online learning software $(\mathrm{Li}$ \& Lalani, 2020).

When the COVID-19 pandemic first arose in March 2020, in-person learning became mostly impossible in many places, including in Poland. As public and non-public schools suspended their traditional activities, the education system shifted towards e-education, with various methods and forms of distance education being rapidly implemented. Schools were forced to shift to the online mode of teaching virtually overnight, which caused numerous difficulties and posed an enormous challenge to the Polish digitalization programme. Legitimate questions arose about whether online education could provide all learners with the right conditions to advance their knowledge and obtain results similar to the ones that would have been achieved during traditional learning. Some of the opinions that were expressed were enthusiastic, while others were sceptical.

Access to the Internet and the quality of the connections, as well as access to such devices as desktop computers, laptops, tablets, and smartphones were important issues. This problem has manifested itself in many countries, in myriad ways. For example, 95\% of students in Switzerland, Norway, and Austria have a computer to work on, compared with only $34 \%$ in Indonesia, according to OECD data. In the United States, there are considerable differences in access to a computer between students from more privileged vs more disadvantaged backgrounds (Li \& Lalani, 2020). In Poland, certain inequalities of opportunity were driven 
by the fact that not all children, adolescents, and students had access to the Internet and/or the necessary hardware. However, many authorities (including local governments), celebrities, and even schools at various levels of education took initiatives to counteract this situation.

Since the situation in the next school/academic year, 2021-2022, remains uncertain at the time of writing this article, the question arises of whether e-education or its selected elements can continue to be used in the teaching process and whether hybrid learning is possible. There is no doubt that learning new solutions in the sphere of e-education is not merely a matter of expedience but a necessity. However, this requires the development of new skills and new student-teacher relationships. In the words of Pawel Poszytek, director general of the Foundation for the Development of the Education System (FRSE), "the pandemic is not only a crisis. It is a tremendous opportunity to test both new educational tools and our competencies" ("Edukacja w czasach pandemii," 2020).

This study reported herein sought to explore the current state of affairs in the Polish e-education market, as perceived by the owners of companies providing commercial educational services and by secondary school and university students who consume educational services. The study was carried out in May 2020, which means early on during the COVID-19 pandemic, and it had a twofold nature. Firstly, to set the stage and gain an overview of the market, in-depth interviews were carried out with eight owners of companies offering e-education services. Next, an extensive online survey was carried out among secondary school and university students concerning their degree of experience with e-education and their satisfaction or dissatisfaction with such services. By surveying two groups of students from different age groups, we sought to compare their behaviour and motivations both before and during the COVID-19 pandemic.

Before these two parts of the present study are presented in detail, however, the next section of this paper sets the current e-learning situation into a broader historical context. 


\section{Some History: From Correspondence Courses to Modern E-Learning}

In the pre-Internet era, distance education involved sending educational materials by regular post between the education institution and its students. This was called "correspondence education" and it is first attested in the early half of the eighteenth century (Penkowska, 2010, pp. 9-10, 14-15). It is assumed that correspondence education started in 1728 in the United States, when the Boston Gazette advertised a correspondence course for the residents of Boston. Those who enrolled in the course had several lessons sent to them by regular post on a weekly basis. The classes were organized by Caleb Phillips, a shorthand teacher. A similar model was noted in Poland in 1776, when the University of Kraków started to offer "vocational courses for craftsmen" (Agnieszka, n.d.).

In the nineteenth century, the method gained increasing popularity. In England, correspondence courses started to include not only shorthand but also English and German language courses. Lessons in the transcription of Bible passages initiated by Isaac Pitman, regarded as the pioneer of distance education (Penkowska, 2010, pp. 14-15), eventually rose to fame. The students were required to transcribe selected chapters into shorthand and send the results to the instructor by letter for grading. The instructor would then add his comments and send the materials back to the students, also by regular post. These can be recognized as early counterparts to today's methods that involve submitting a draft assignment online using an e-learning platform for subsequent grading by the teacher/lecturer.

As distance education flourished, universities and other higher education institutions became the main centres offering correspondence courses. Their scope was broadened, and the lessons were modernized and modified. Important figures in the field of correspondence education included Anna Eliot Ticknor, who founded the Society to Encourage Studies at Home (SH) in the United States in 1873. The organization offered distance courses in 24 subjects (Penkowska, 2010, p. 15).

With the development of technology, remote education underwent successive transformations. The distance education market grew 
rapidly in the twentieth century, characterized by a number of new inventions enabling the transmission of information, such as radio, television, computers and the Internet. In the United States and Australia, educational radio started to be used, which facilitated education in sparsely populated regions and in rural areas, where no traditional schools operated (Dąbrowska et al., 2013, p. 30). The year 1945 witnessed the emergence of what was called educational television, and the 1960s marked the beginning of the computer age, with computers gradually starting to take centre stage at numerous universities around the world, with the United States being the leader in this field.

Once computers became commonplace, it was only a matter of time before e-learning gained popularity. The first e-learning platform, called PLATO (Programmed Logic for Automatic Teaching Operations), was created in 1965 at the University of Illinois and continued to operate until 2006. Many of today's multi-user concepts (such as forums, online testing, e-mail, chat rooms for real-time conversations, instant messaging, screen sharing and multiplayer video games) were originally developed on PLATO. By the standards of its times, PLATO was a highly innovative system (Dąbrowska et al., 2013, p. 30).

The 1990s witnessed the rapid global expansion of the Internet. Exploring the opportunities it offered made education possible in almost every place in the world with network access. The Internet enabled unrestricted communication, real-time conversations and interactions between teachers and students, an immediate transfer of knowledge and the removal of the barriers of time and space. E-learning developed largely thanks to advancements in digital telecommunication, as well as multimedia and satellite technology. Educational institutions and universities were established that offered fully remote studies ending in the awarding of a diploma. Radio and television courses were replaced by videoconferences, which were later displaced by online education (Penkowska, 2010, pp. 17-18, 62-63).

The next step in the expansion of e-learning is related to the development of mobile technology. Opportunities offered by the ubiquity of mobile phones and smartphones, which are much smaller in size than computers, contribute to the growing popularity of such devices in 
e-education. A phenomenon referred to as media convergence has changed the existing framework of the use of basic education tools, primarily the Internet. It can now be accessed using various devices, not only computers, and e-learning with the help of mobile phones, pocketsize tablets and smartphones is rapidly gaining popularity, which necessitates the adaptation of educational courses to continually shifting mediums.

Numerous inventions in the field of data transmission and their various applications have pushed down the costs of education, thus making it more accessible. Inequal opportunities in access to knowledge among various social groups have been gradually reduced.

Some of the ways e-education (also referred to as e-learning, online education, and distance education) has been defined in the literature are as follows:

- as a form of education conducted via electronic media, including computer networks, as well as satellite, radio and television broadcasts. Here e-education is understood as an interactive method of education based on the use of the latest developments in information technology (IT), with the teaching content and related information being transmitted primarily through the Internet, but also through local area networks (LANs), often with the use of audio-visual materials, DVDs, etc. On this approach, e-education comprises a wide range of learning technologies and methods; it combines self-directed learning with the use of selected electronic tools and traditional methods by which students learn from lecturers (Stecyk, 2006, p. 295-300);

- as "a teaching process that takes place in a non-school environment (derived from the concept of distance learning/distance education) and aims to create new quality in learning by using modern multimedia ICT solutions in the education process" (Kuźmicz, 2012, p. 130). Here e-education is understood as a process conducted using various tools, in particular desktop computers and laptops, notebooks, tablets, graphics tablets, mobile phones, PDAs (Personal Digital Assistants) ${ }^{2}$ and smart TVs;

- as a type of teaching and learning process that represents the whole of the educational model applied or a part thereof with the use of new 
information and communication technologies that enable communication, interaction and remote access to educational materials. Here, e-education is seen as promoting the acceptance of new approaches to education and its development (Szczepaniak-Sobczyk, 2018, p. 66).

The COVID-19 pandemic that began in 2020 has necessitated an unprecedented and vast increase in the transfer of knowledge through e-education. In this mode of teaching, it is chiefly the student, not the teacher, who is required to plan the process of acquiring knowledge and achieving the desired results. Young people are increasingly eager to explore new educational opportunities, online content and educational computer games. Teachers and authors of curricula are trying to adapt the educational process to these new opportunities. There is a visible tendency to increase effectiveness, optimize time management and focus on the most important activities, namely work and leisure time.

The most popular consumer trends currently observed in e-learning include:

- blended learning (Penkowska, 2010, pp. 106-107);

- mobile learning (Hejduk, 2009, p. 43);

- augmented reality (the physical world is combined with electronic data and images; Szczepaniak-Sobczyk, 2018, pp. 168-169),

- artificial intelligence (such as homework solving and speech recognition applications), machine learning (such as coding, language learning, supporting teachers by aggregating student data in one place), and MOOCs (massive online access courses, which target an unlimited number of users and allow open access via the Web; Kwiatkowska, 2018, pp. 51-52);

- MOOCs (massive online access courses, which target an unlimited number of users and allow open access via the Web); (Kwiatkowska, 2018, pp. 51-52);

- open educational resources (open databases offered increasingly frequently by higher education institutions); (Dąbrowska et al., 2013, p. 53); 
- intelligent multimedia textbooks (for example the Semantic Web); (Banachowski, 2013, p. 11);

- personalized education programmes (in both non-public and public schools, especially in higher education institutions); (Madej et al., 2016, p. 15),

- popular information sources (the ability to search for and find relevant information; (Banachowski, 2013, p. 15),

- social learning (acquiring individual, professional, practical and emotional skills through collaboration with other group members); (Dąbrowska et al., 2013, p. 43); and

- gamification (learning through games); (Margulis, 2005).

\section{Materials and Methods}

This study, seeking to examine the situation in the Polish e-education market in the post-COVID-19 realities, comprised two parts. Firstly, to set the stage, a qualitative survey was conducted among owners of companies who provided educational services. Secondly, an extensive quantitative survey on was carried out among consumers of educational services (secondary school and university students); by surveying both service providers and two groups of students from different age groups, we could study their behaviour and motivations both before and during the COVID-19 pandemic. Each of these two sources of information will now be described in turn.

\section{Qualitative survey among education service providers}

The qualitative survey was conducted among owners of companies that provide educational services: online tutoring, video courses, email courses, webinars and dedicated e-learning platforms. Eight such individuals were selected in a targeted sample, with whom in-depth interviews of this sort were conducted. The interviews were structured around the objective of addressing questions relating to the situation their companies found themselves in during the COVID-19 pandemic. Some of the interviewees' companies had previously provided traditional in-person educational services but due to lockdown measures had been forced to temporarily suspend this form of teaching. 


\section{Quantitative study among education service consumers}

The quantitative survey among consumers was carried out among two groups: final-year secondary school students (group I) and university students (group II). The questionnaire survey was carried out using Computer-Assisted Web Interviewing (CAWI) - an Internet surveying technique in which the interviewee follows a script provided on a website - on 10-25 May 2020. It is perhaps worth stressing that this was a time when the use of e-education during the COVID-19 pandemic was still an largely unstudied phenomenon.

The questionnaire survey was correctly completed by a total of 803 respondent Of this number, 30\% (243 respondents) were members of group I and 70\% (560 respondents) belonged to group II. The survey was conducted using the CAWI method (computer-assisted web interviewing) and purposive sampling. The study questionnaire comprised 20 thematic questions, including 17 closed-ended questions and three open-ended questions. In addition, the questionnaire included five demographic questions related to: the type of education institution (public/non-public), the type of studies or the class curriculum profile in secondary school, the mode of studies (full-time/part-time studies), the city in which the respondent learnt and gender. Filter questions were used to find out whether respondents had used e-learning during the coronavirus pandemic and whether they had done so before its outbreak. In this way, we selected a group of respondents that met the sampling criteria.

Among the respondents in group I, 65\% attended general secondary schools, 33.3\% attended technical secondary schools, and the remaining 1.6\% indicated the answer "other." Group I was characterized by a significant prevalence of women $(86.4 \%)$ over men $(13.6 \%)$.

In the survey of university students, $97.5 \%$ of the respondents studied at public universities, compared with $2.5 \%$ enrolled at private universities. Among those surveyed, $61 \%$ pursued first-cycle programmes (bachelor's/engineer's degree), 27.5\% pursued second-cycle programmes (master's degree), and $11.5 \%$ pursued long-cycle programmes. Among the respondents, 495 were full-time students, and 65 were part-time students. Group II was likewise characterized by a significant prevalence of women (82\%) over men (18\%). Among the cities in which the respondents learnt, the most frequently provided answer was Warsaw (190 respondents), followed by Wrocław (124), 
Kraków (93), Toruń (88), Rzeszów (18) and Lublin (7). Other cities received single answers from the respondents.

The surveys were conducted in May 2020.

\section{Results}

\section{E-Education From the Perspective of Service Providers}

The qualitative interviews carried out with providers of education services revealed that after the COVID-19 pandemic broke out, they noted an increase in interest in products aimed at secondary school students. Moreover, they attributed this situation to the upcoming final exams and students' dissatisfaction with online education organized by schools, which prompted learners to search for additional sources of knowledge. In addition, such services also provided a way for young people to spend their free time during the lockdown. However, the respondents also stressed that the demand for online education among adults had dropped during the pandemic, which they in turn blamed on the uncertain situation in the labour market, concerns about job stability and job loss and cost-cutting, including at the companies that had financed such services for their employees. When asked about the prevailing trends in the education market before the COVID-19 pandemic, the respondents consistently pointed to a growing interest in in-person tutoring. As for online education, however, they provided highly diversified answers, pointing to a steady rise in the popularity of online tutoring and e-learning platforms, as well as a decline in the popularity of email and video courses.

The respondents listed the following reasons for the increased demand for online tutoring: wishing to save time on commutes, being accustomed to using computers/mobile devices to work and do various other activities, an easier time overcoming the language barrier for shier people and enjoying greater anonymity. They argued that students found it a lot easier to "open up" when interacting via Skype, for instance, than when interacting in person, in direct contact with people who might be seen as judging them. 
As for the advantages of e-learning platforms, the owners surveyed pointed out the accumulation of knowledge presented in different forms (such as text, audio, video and image files) in one place, as well as uniform ways of tapping into them, which translated into intuitive navigation.

The respondents also pointed to growing competition. Before the pandemic, many companies knew very little about digital marketing, which meant higher conversion rates in advertising campaigns on Facebook and those using Google Ads. Internet marketing is now much more popular, and email marketing campaigns are a lot less effective for reasons related to the oversaturation of this form of communication, which impacts on the possibility of winning customers. In addition, the market is increasingly saturated with online courses, which are relatively easy and inexpensive to organize. Mounting price competition is pushing down the profitability of businesses.

According to a majority of the respondents, the devices predominantly used by their customers for e-learning are laptop computers. At the same time, the percentage share of those using mobile phones (smartphones) in the education process is a lot greater than five years ago. The rising curve of the use of mobile devices and the gradually declining curve of the use of desktop computers in the e-education process is evidence of a trend known as mobile learning.

\section{E-Education From the Perspective of Final-Year Secondary School Students}

Secondary school students, including final-year secondary school students, reported that they are particularly motivated to use educational services outside of school for reasons related to their secondary school graduation exams (known as the matura in Poland) - not only to pass the exams, but also to prepare for them as well as possible and obtain good results, which will help them get into their target universities. University students, on the other hand, reported that they are motivated by the prospect of mid-term and final exams, the desire to change their study path, interest in increasing their knowledge capital and the acquisition of 
additional skills, which they will be able to use on the labour market in Poland and abroad.

A vast majority of the secondary school students we surveyed (92.6\%) said that they participated in online lessons provided by their schools, which demonstrates not only that students participate in online education but also that schools do organize and conduct such classes. Among the respondents, 2.5\% provided negative answers, i.e. they did not attend remote classes, despite the fact that such lessons were provided by their schools. Reasons for this could include not only reluctance to participate, but also the absence of adequate technical infrastructure. According to data from Statistics Poland (GUS), 84.2\% of Polish households had access to the Internet in 2018 (Orczykowska, 2018), compared with 90.4\% in 2020 (Wegner, 2020), which translates into a rise of 6.2 percentage points. In the study, $4.9 \%$ of the respondents declared that their schools did not provide additional distance education, so they had to learn by themselves, using available sources or paid forms of e-education services to pass their exams with good results.

The respondents were then asked about the forms of e-education provided by their schools. The most frequently used tools included textbased materials sent by email (197 responses), live online classes (149 responses) and education platforms (97 responses). Audio and video materials, e-books and educational games were less likely to be used. The respondents who answered that they participated in live online classes were asked about the tools most commonly used by teachers in communication with students to conduct lessons. The most popular platform for live online classes was Microsoft Teams, followed by Zoom, Skype and Discord. Other tools that were mentioned included Facebook Messenger, Google Hangouts, Google Meet, WhatsApp and Webex. Participants in online school education were asked to rate their satisfaction with the classes they attended and the methods of conducting them on a seven-point Likert scale (one - strongly dissatisfied, two dissatisfied, three - somewhat dissatisfied, four - no opinion, five somewhat satisfied, six — satisfied, seven — strongly satisfied). The most frequently indicated ratings were "four" and "five" $(22.9 \%$ of all answers each), which means that secondary school students were, on balance, moderately satisfied with this form of education. 
Secondary school students were also asked to identify the advantages and disadvantages of e-learning. The advantages they named included: flexible learning hours, the possibility of lengthening or shortening lessons without waiting for the school bell to ring, delayed start times compared with traditional education, teacher engagement, no need to commute to school, the possibility of assuming any posture or position during remote lessons, no need to show one's face, greater understanding on the part of teachers, a relaxed atmosphere, less stress, a greater ease of obtaining good grades, autonomy, the ability to review the material at one's own pace, no time pressure and the possibility of getting up later. The list of the disadvantages they named included: a lot of time spent in front of a computer screen, a lower motivation to learn, too wide a variety of the programmes used, no access to all materials on a single platform, no direct contact with teachers and peers, a low level of engagement on the part of some teachers, no access to selected technologies or problems with using them, such as poor sound quality during live classes and connectivity issues due to the poor quality of the Internet connection, difficulties in providing access to electronic devices for all students and teachers, no individual approach to students in case of problems, difficulties in contacting teachers, failure to explain the topics under study - only the submission of assignments and answers, easier distraction, the need to devote some time to organizational issues, which means that less time is left for actual learning, and too much homework. Many respondents pointed to difficulties especially in learning mathematics, because teachers focus mainly on speaking and there is no possibility of simultaneously writing anything down on the blackboard. The list of the disadvantages mentioned appears to be longer than the benefits that were observed.

Respondents were also asked whether they used e-learning services outside of school (including paid services) during the 2019-2020 school year. Affirmative answers were given by $61 \%$ of those surveyed, of which one-in-three had used commercial e-education, compared with $39 \%$ who did not use paid services. Online tutoring and video courses proved to be the most frequently named forms of e-education (Fig. 1). 
Figure 1. Forms of e-education utilised by the secondary school students surveyed in this study (number of responses mentioning this form)

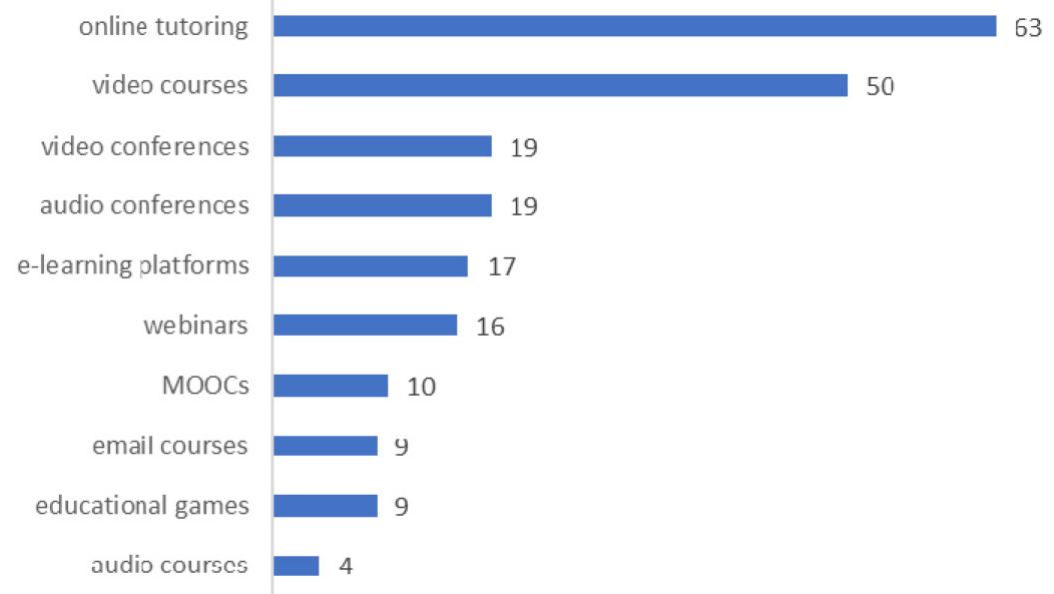

In order to compare the behaviour of final year secondary school students before and during the COVID-19 pandemic, we asked them whether they had used paid forms of e-education before the pandemic. Among the respondents, 21\% answered affirmatively, while 79\% answered negatively. Importantly, the share of positive answers was $33 \%$ before the pandemic, which implies growth in the demand for paid e-learning services. Once the pandemic ends, schools may return to traditional teaching methods, but some of the elements of e-learning will become a permanent part of education. It could be said that many people have realized that harnessing the latest technologies creates new opportunities in the education process and allows the transition to remote learning, thus causing a transformation of the existing education model.

When respondents were asked to rate their satisfaction with the paid elearning services on a seven-point Likert scale, the answers were clearly dominated by favourable opinions: $39.8 \%$ of the respondents were satisfied (six points) and $16.1 \%$ were very satisfied (seven points). By contrast, the ratings of four (no opinion) and five (somewhat satisfied) were most frequently selected when the respondents were asked to rate their satisfaction with e-education provided by their schools. 
We also analysed the use of free out-of-school e-learning services by the respondents. The results we obtained indicate that those services were dominated by text and video materials, which received more than twice as many answers as audio materials and free e-learning platforms (Fig. 2). Single responses pertained to open webinars, as well as tutoring on television.

Figure 2. Use of out-of-school, cost-free e-learning services

by the secondary school respondents of the survey (number of responses)

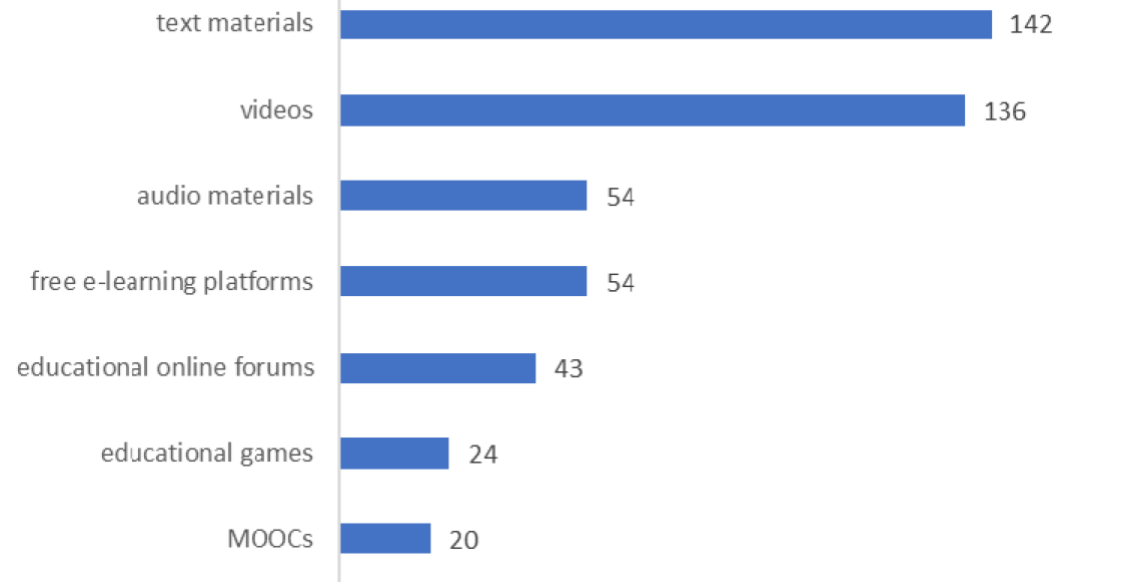

The main reasons why the respondents used paid e-learning services were: a desire to better prepare for exams (60\% of answers), insufficient education at school (41\%), the possibility of individual teaching (34.5\%), a desire to get into a specific university programme (34\%), better efficiency (25\%), better adjustment to needs $(23 \%)$, round-the-clock access $(20 \%)$ and self-paced learning (20\%).

Secondary school students who used paid e-learning services perceived video materials as the most effective form of online education, listing such advantages as better efficiency of learning/working, reduced effort and a lot simpler explanations of specific problems. 
Interesting results were obtained regarding the devices used by secondary school students for e-learning purposes. Respondents' answers were dominated by computers (including laptop computers), which accounted for $61 \%$ of the responses, followed by mobile phones and smartphones (26\% of responses), whereas the use of a tablet was indicated by a mere $3 \%$ of respondents. Computers may be the most popular devices for reasons related to larger screen sizes, which translates into easier access to a variety of functions and bookmarks without the need to swipe. Ease of navigation is also a very important factor behind the choice of learning tools.

\section{E-Education From the Perspective of University Students}

In the survey of university students, the study questionnaire was filled in by 560 respondents. As many as $99 \%$ of the respondents answered affirmatively to the filter question about the use of e-education services organized by their universities during the COVID-19 pandemic in the 2019-2020 academic year. Negative answers, which accounted for $1 \%$ all responses, may have resulted from technical problems of specific university units (no adequate hardware, no Internet access) or the independent decision made by the students who did not want to participate in this form of education, despite the fact that it was offered by their universities. Among those surveyed, 82\% admitted to attending live classes, which resemble traditional education to the greatest degree. Respondents obtained study materials from a variety of sources (Fig. 3).

The results we obtained led us to the conclusion that universities used education platforms to offer remote education, which allowed them to place scientific content presented in different forms in a single place. This approach allowed better organization of work, reduced the time spent searching for required content, and allowed easier navigation of topics and information. 
Figure 3. Sources from which the university students surveyed in the present study reported that they obtained study materials

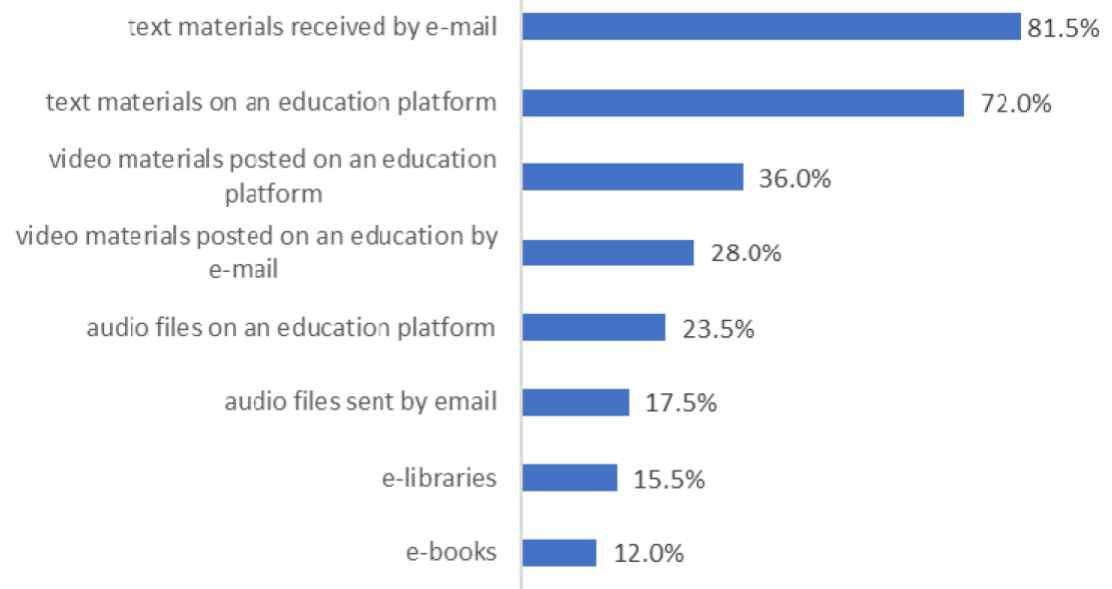

Live online classes were primarily conducted using: Microsoft Teams (54\% of answers), followed by Zoom (19\%), Skype (7\%) and Google Meet $(6.5 \%)$. As for other platforms, we noted significant interest in BigBlueButton (3\%), Cisco Webex (3\%) and Facebook Messenger (2.5\%). For reasons related to the wide variety of products used, which were new to many students, we asked the respondents whether they had any problems using such programs during their first online class. Two thirds of the respondents declared that had no problems, which indicates that young people, raised in the era of the technological revolution and wide expansion of the Internet, learn to use new Internet communication tools very quickly and navigate them intuitively.

When asked about their attitudes towards e-education organized by their universities, two fifths of the respondents admitted that they were curious about classes taught in this form and one fourth were not satisfied with the change, whereas one sixth were of the opposite view. The remaining respondents felt indifferent.

Importantly, $60 \%$ of the students surveyed declared that they always participated in online classes, $27 \%$ stated that did so almost always, and only $3.5 \%$ did not participate in remote classes. The main reasons for high 
student participation in classes included mandatory attendance (checked by instructors), curiosity about e-learning courses and satisfaction with e-lessons.

The university students surveyed were also asked to rate their subjective satisfaction with distance learning organized by their universities on a seven-point Likert scale (one - strongly dissatisfied, seven - strongly satisfied). The responses were dominated by ratings on the higher side of the scale, which expressed satisfaction. Almost one third of the respondents gave distance learning a rating of five (somewhat satisfied), whereas the ratings of six (satisfied) and four (hard to say) were selected by one fifth of the respondents each. Six percent rated distance organized by their universities at seven (strongly satisfied), whereas $5.5 \%$ gave it a rating of one (strongly dissatisfied).

The respondents were also asked whether they availed themselves of any e-education services outside those offered by university. Among the university students surveyed, 36\% answered affirmatively. As many as $91 \%$ of them used paid forms of online learning. The most common forms of commercial e-learning services they used were webinars (34.6\%), followed by e-books (31.8\%), e-learning platforms $(29.6 \%)$ and video courses $(28.5 \%)$. Less importance was given to audio- and videoconferencing (14.5\%), email courses (14\%), online tutoring (8.9\%), MOOCs $(6.7 \%)$, educational games $(5.6 \%)$, audio courses $(4.5 \%)$ and learning apps $(2 \%)$.

Importantly, one in four university students made use of commercial e-learning services to pursue their passions and interests, pursue selfdevelopment and gain additional professional qualifications. The topics studied by students were primarily foreign languages. A substantially smaller respondents learnt computer skills via this medium, but some of them also expanded their knowledge in such fields as economics, psychology, mathematics, law, the Polish language and marketing.

The vast majority of respondents (80\%) declared that the COVID-19 pandemic had affected their interest in e-learning. Before the pandemic, e-books were the most popular form of e-learning, but they were replaced by webinars. The position of e-learning platforms and video courses remained unchanged, but an increased interest in email courses was noted. 
When choosing between various e-education services, the university students we surveyed reported that were mostly guided by a desire for self-development (55\%), followed by the absence of traditional classes (29.5\%), the possibility of choosing when they could learn (28\%), the improvement of qualifications (27\%), round-the-clock access $(25 \%)$, selfpaced learning (25\%), no need to commute $(22 \%)$ and the possibility of individual teaching (21\%). Students were satisfied with the paid eeducation services they used.

When asked about the effectiveness of specific e-education services, students primarily indicated video courses (28\%), live classes (27\%) and e-learning platforms (15\%). Among the devices they used for e-education, $77 \%$ named a computer, whereas $21 \%$ indicated a mobile phone/smartphone.

\section{Discussion}

The spread of new technologies goes hand in hand with the development of e-education. Innovations in the IT sector, such as artificial intelligence, machine learning, virtual and augmented reality, are all changing the image of education and educational tools. At the same time, a significant increase in the use of mobile devices and other such factors are making it increasingly necessary to adapt educational products to the changing needs of consumers. On top of this already complex and changing e-learning landscape, the COVID-19 pandemic that began in early 2020 brought with it unexpected and quite significant dynamics in the educational setting in general, and the e-learning services market in specific.

Poland is certainly not unique in this respect. Based on a survey of students from the largest public universities in the United States, Aucejo et al. (2020) found that the pandemic affected all students, but its impact was more disruptive to lower-income students. The authors blame this situation on the fact that lower-income students are more financially vulnerable to the pandemic and more concerned about immediate virusrelated health risks. The students who completed the survey stated that 
their learning capacity in the spring semester had been affected negatively by the COVID-19 pandemic. Citing research by Kuhfeld et al. (2020), the authors argue that the declining educational value of universities amidst COVID-19 is consistent with new evidence regarding the situation of primary and secondary school students.

The study reported herein examined the situation in the Polish market of e-education services, seeking greater insight into the existing realities and perceptions in the wake of the onset of the pandemic. The study comprised two parts: a qualitative survey conducted among owners of companies that provide commercial e-educational services regarding their perceptions of the market, and a broader quantitative survey among consumers of educational services (secondary school and university students) concerning the degree to which they avail themselves of such services and their levels of satisfaction and dissatisfaction with e-education.

As for the qualitative survey of service providers, it found that they when the pandemic broke out, they - perhaps unsurprisingly - noted a surge in interest in online education. However, this surge was not across the board: while interest in products aimed at secondary school students and university students went up, the demand for online education among adults had dropped. Moreover, they reported that the market is quickly becoming increasingly difficult for reasons related to mounting competition, pushing down prices. The respondents reported that digital marketing and e-mail marketing had become less effective, and attributed the growing interest in online tutoring to the absence of direct contact between students and those who could evaluate them. Overall, the findings from the qualitative survey among service providers seem to indicate the COVID-19 pandemic brought the intensification of earlier trends (e.g. towards more on-line tutoring), while also brining considerable instability to the market.

As for the quantitative survey of secondary school students and university students, both groups were found to be characterized by a high level of participation in the classes organized by their schools, but this level was somewhat higher in the latter group (by six percentage points). The forms of e-education were dominated by text-based materials in 
secondary schools, compared with text-based materials and live classes in universities. The programme most commonly used for the purpose of live classes, in both secondary and university education was Microsoft Teams, followed by Zoom and Skype. The main reason behind the use of online learning was the desire to better prepare for secondary school graduation exams for secondary school students, and self-development for university students.

Compared with secondary school students, university students were more satisfied with e-learning offered by the educational institution they attended. A much higher percentage of secondary school students used out-of-school e-education services (61\%, compared with $31 \%$ for university students). One in five respondents in each group had used selected forms of paid e-education before the pandemic, with COVID-19 clearly driving up demand for such services.

Both groups of students under study were generally satisfied with paid e-learning services, although they did also list numerous disadvantages of such forms of education. Importantly, however, the survey was conducted not long after the beginning of the pandemic (in May 2020), which means that the reactions of the respondents may also have been based on emotional reactions to some extent. In any case, the findings reported herein are coherent with international research suggesting that online learning helps students absorb information more quickly and takes less time, which means that the changes in the organization of education necessitated by the spread of the coronavirus may be here to stay. Other research (Li \& Lalani, 2020) has shown that students retain 25-60\% more material on average in e-learning settings (versus $8-10 \%$ in traditional learning); in addition, e-learning allows students to learn at their own pace and requires $40-60 \%$ less learning time than traditional education. In turn, McDougall et al. (2020) found that online classes could be as effective as traditional lessons, but a great deal depended on the use of "active learning" techniques by students.

However, it should be recognized that the pandemic has likewise been disruptive to teachers. Not all of them had even basic skills in the use of Internet and communication technologies or previous experience with providing high-quality online education. This has been confirmed by 
a study carried out in Latvia (Svence et al., 2020). Continued efforts are therefore necessary to improve the technological skills of all those involved in the education process.

Education is the foundation of the functioning and development of human beings and allows them to fulfil their needs for self-education and self-actualization. Moreover, e-learning has become an integral part of not only university studies but also at lower levels of education. The Internet can be used by learners around the world to immediately find information on practically any topic and access educational materials practically at no cost, and by teachers to share their knowledge and experience (Sharma, 2020). At the same time, a result of the uncertainty caused by the COVID-19 pandemic and its changeability over time, it is difficult to project changes in the demand for various forms of e-learning in the near future. Undoubtedly, e-learning, despite the criticism it has attracted, has made it possible to continue the educational process during the lockdown period. Numerous related topics are being discussed the literature - such as in Pyżalski (2020), a collection of articles on education during the COVID-19 pandemic, addressing such issues as remote education tools, wise education, teacher well-being, collaboration between teachers, digital inequalities, peer relationships, collaboration with parents/guardians, digital competence and student engagement.

The study reported herein may serve as a valuable point of reference in this ongoing research into the continually shifting e-learning landscape, as a certain snapshot of practices, attitudes and perceptions at a particular place and a particular moment in time (in Poland, in May 2020, during the first wave of the COVID-19 pandemic). As such, this study can be seen as a contribution to further research and observation. A great deal of space has recently been devoted to the assessment of the functioning of educational institutions, limited access to the Internet and by the same online education and organization of online classes. It can be assumed that the future waves of COVID-19 infections will encourage researchers to study in greater detail the behaviour of consumers (secondary school and university students) in the market of commercial e-education services. 


\section{Endnotes}

${ }^{1}$ Compulsory schooling in Poland is regulated in the Act of 14 December 2016 - Education Law (Journal of Laws 2020, Items 910 and 1378). Under Article 35(2), the period of compulsory education starts at the beginning of the school year in the calendar year in which a child reaches the age of seven years and continues until he or she completes primary school education, but no longer than until the child reaches the age of 18 years.

${ }^{2}$ PDAs are very small, portable personal computers that fit into the palm of a hand or into a pocket and have a touch screen that is operated with the use of a stylus.

\section{References}

1. Agnieszka (n.d.). Historia e-learningu na świecie $i w$ Polsce [History of e-learning in the world and in Poland; blog post]. Heuristic. Retrieved February 2, 2020, from https://www.heuristic.pl/blog/e-learning/Historia\%20e-learningu\%20na\%20\% C5\%9Bwiecie\%20i\%20w\%20Polsce;161.html

2. Aucejo, E., French, J., Ugalde Araya, P., \& Zafar, B. (2020, August 9). COVID-19 is widening inequality in higher education. VoxEU.org (CEPR Policy Portal). https://voxeu.org/article/covid-19-widening-inequality-higher-education

3. Banachowski, L. (Ed.). (2013). Postepy e-edukacji [Advances in e-education]. Wydawnictwo PJWSTK.

4. Dąbrowska, A., Szepieniec-Puchalska, D., Radziukiewicz, M., \& Szymańska, A. (2013). Znaczenie e-ustug spotecznych dla wspótczesnego konsumenta [The importance of social e-services for modern consumers]. Instytut Badań Rynku, Konsumpcji i Koniunktur.

5. Dhungana, S. (2020, June 25). Covid-19 lockdown affects Nepali students planning to go abroad. The Kathmandu Post. https://kathmandupost.com/national/2020/06/25/covid-19lockdown-affects-nepali-students-planning-to-go-abroad

6. Edukacja w czasach pandemii. Wszyscy jesteśmy uczniami [Education in the times of the pandemic. We are all learners]. (2020, April 24). Rzeczpospolita. https://www.rp.pl/biznes/art756291-edukacja-w-czasach-pandemii-wszyscy-jestesmyuczniami

7. Hejduk, I. K., \& Grudzewski, W. M. (2009). Edukacja w cyberprzestrzeni: Paradygmaty wspótczesnego ksztatcenia na odlegtość [Education in cyber space: Modern distance education paradigms]. Wydawnictwo Katolickiego Uniwersytetu Lubelskiego.

8. Kuhfeld, M., Soland, J., Tarasawa, B., Johnson, A., Ruzek, E., \& Liu, J. (2020). Projecting the potential impacts of COVID-19 school closures on academic achievement (EdWorkingPaper: 20-226). https://doi.org/10.26300/cdrv-yw05

9. Kuźmicz, K. (2012). E-edukacja jest wszędzie - rozważania dotyczące istoty i zastosowania technologii mobilnych w kształceniu zdalnym [E-education is everywhere - reflections on the essence and applications of mobile technologies in remote education]. In A. Dytman-Stasieńko, J. Stasieńko (Eds.), Język@ multimedia: dialog konflikt (pp. 129-140). Wydawnictwo Naukowe Dolnośląskiej Szkoły Wyższej.

10. Kwiatkowska, W. (2018). Mozaikowy wizerunek uczacych się w uniwersyteckim ksztatceniu on-line [The mosaic image of learners in university-level online education]. Wydawnictwo Naukowe Uniwersytetu Mikołaja Kopernika. 
11. Li, C., \& Lalani, F. (2020, April 29). The COVID-19 pandemic has changed education forever. This is how. World Economic Forum. https:/www.weforum.org/agenda/2020/04/ coronavirus-education-global-covid19-online-digital-learning

12. Madej, M., Faron, A., \& Maciejewski, W. (2016). E-learning w dydaktyce szkoty wyższej - zatożenia, doświadczenia, rekomendacje [E-learning in higher education assumptions, experiences, recommendations]. Wyższa Szkoła Handlowa we Wrocławiu.

13. Margulis, L. (2005). Gry w wirtualnym środowisku nauczania [Games in a virtual learning environment]. E-mentor, 1(8), 83-86.

14. McDougall, A., Orlov, G., \& McKee, D. (2020, December 10). Learning during the COVID-19 pandemic. VoxEU.org (CEPR Policy Portal). https://voxeu.org/ article/learning-during-covid-19-pandemic

15. Orczykowska, M. (2018, October 22). Społeczeństwo informacyjne $w$ Polsce $w 2018 \mathrm{r}$. [Information society in Poland in 2018]. Statistics Poland. https:/stat.gov.pl/ download/gfx/portalinformacyjny/pl/defaultaktualnosci/5497/2/8/1/spoleczenstwo_infor macyjne_w_polsce_w_2018_roku.pdf

16. Penkowska, G. (2010). Meandry e-learningu [Meanders of e-learning]. Difin.

17. Pyżalski, J. (Ed.). (2020). Edukacja w czasach pandemii wirusa COVID-19 [Education during the COVID-19 pandemic; e-book]. EduAkcja.

18. Sharma, V. (2020, April 12). E-Learning in the era of COVID-19 pandemic. Daily Excelsior. https://www.dailyexcelsior.com/e-learning-in-the-era-of-covid-19-pandemic

19. Stecyk, A. (2006). Charakterystyka systemów e-learning w globalnym systemie informacyjnym [Characteristics of e-learning systems in the global information system]. In M. Gwoździcka-Piotrowska \& A. Zduniak (Eds.), Edukacja w społeczeństwie „ryzyka”. Bezpieczeństwo jako wartość (Vol. 1, pp. 295-300). Wydawnictwo Wyższej Szkoły Bezpieczeństwa w Poznaniu.

20. Strauss, V. (2020, April 6). Schools of more than 90 percent of the world's students closed during this pandemic. This graphic shows how fast it happened. The Washington Post. https://www.washingtonpost.com/education/2020/04/06/schools-more-than-90percent-worlds-students-closed-during-this-pandemic-this-graphic-shows-how-fast-ithappened

21. Svence, G., Gajdasova, E., Petrulyte, A., Kalnina, L., Lagzdina, L., \& Pakse, I. (2021). Teachers' social and emotional health indicators in the distance learning situation during the COVID-19 pandemic. Problems of Psychology in the 21st Century, 15(1), 26-38. https://doi.org/10.33225/ppc/21.15.26.

22. Szczepaniak-Sobczyk, L. (2018). E-learning $w$ edukacji humanistycznej [E-learning in education in the field of humanities]. Wydawnictwo Uniwersytetu Gdańskiego.

23. United Nations. (2020, August). Policy Brief: Education during COVID-19 and beyond. https://www.un.org/development/desa/dspd/wp-content/uploads/ sites/22/2020/08/sg_policy_brief_covid-19_and_education_august_2020.pdf

24. Wegner, M. (2020, October 21). Społeczeństwo informacyjne $w$ Polsce w $2020 \mathrm{r}$. [Information society in Poland in 2020]. Statistics Poland. https://stat.gov.pl/ download/gfx/portalinformacyjny/pl/defaultaktualnosci/5497/2/10/1/spoleczenstwo_info rmacyjne_w_polsce_w_2020.pdf 
Prof. Anna Dąbrowska - Warsaw School of Economics in Warsaw, Collegium of Management and Finance. She is the head of the Consumer Behaviour Research Department at the Institute of Management. Her academic and research interests focus on consumer behaviour, the marketing of services, the sphere of services in the broad sense, consumer competence and social responsibility, as well as the protection of consumer rights.

Joanna Ciupak, MA - a graduate of the Warsaw School of Economics in Warsaw 